\title{
4 \\ The Turn of the Screw, or \\ The Gothic Melodrama of Modernism
}

\begin{abstract}
The driver braked to what was almost a stop, turned round and slid the glass panel back: The jolt of this flung Mrs. Drover forward till her face was almost into the glass. Through the aperture driver and passenger, not six inches between them, remained for an eternity eye to eye. Mrs. Drover's mouth hung open for some seconds before she could issue her first scream. After that she continued to scream freely and to beat with her gloved hands on the glass all round as the taxi, accelerating without mercy, made off with her into the hinterland of deserted streets. ${ }^{1}$

-Elizabeth boWen, the DeMon lOVER, AND OtHer STORIES (1945)
\end{abstract}

For a number of mid-century critics, The Demon Lover fell squarely within the Gothic tradition. One of the best-known and most-anthologized of Elizabeth Bowen's short stories, it tells the tale of a middle-aged housewife who discovers a mysterious letter-from her undead childhood sweetheart-awaiting her when she returns home. The letter concludes with a sinister warning: "You may expect me . . a the hour arranged." When the clock strikes seven, the protagonist is kidnapped and driven off into the distance by the eponymous demon. As in most Gothic novels, the setting holds immense significance as a purveyor of suspense. Most of the story is spent describing the desolate townhouse that, in spite of its urban setting, has all the "unfamiliar queerness" of the Gothic castle: the warped doors, the dark and narrow staircase, and the "cracks in the structure" all offer a sense of impending horror. And then, in the final paragraph, the subtle hues of the mysterious setting cede to a dramatic black-and-white; pregnant silence gives way to deafening screams; and intangible phantoms become gaudy flesh, as the sentimental heroine comes face to face with a monster.

This melodramatic conclusion was obviously The Demon Lover's deepest bow to Gothic tradition. While one early critic lauded the tale as one of the few "real" or "old-fashioned" ghost stories, Hugh Bradenham lamented that an otherwise discriminating writer should welcome "visitors from another world ... whose normal 
purpose in fiction is to bring about crude changes in a melodramatic plot."3 Yet for every critic who acknowledged the story's Gothic melodrama, there were others who disavowed it entirely, claiming The Demon Lover as a paradigm of modernist restraint, an up-to-date ghost story whose specters were more symbolic than literal. ${ }^{4}$ Perhaps unsurprisingly, defensiveness has only increased as scholars and critics have sought to secure a place for Bowen in the modernist canon. Seizing on aspersions cast on the narrator's sanity, commentators often maintain that The Demon Lover is more a tale of psychological delusion than of ghostly apparition. ${ }^{5}$ Still other writers find additional means of demystifying the mysterious demon. As Sarah Dillon has pointed out, this apparently simple tale in the Gothic mold has become the focus of a complex and often heated hermeneutic debate, one that continues to rage on even today. ${ }^{6}$

Premiered less than a decade after The Demon Lover hit the bookshelves, Britten's Turn of the Screw (1954) has provoked many of the same debates. Based on Henry James's novella of the same name published in 1898, it tells the story of a Governess who, charged with the care of two young orphans at their country estate, becomes locked in a battle over their souls with a pair of resident ghosts. Aside from deploying many of the same sinister edifices and ominous objects as Bowen's story, the opera went even further in giving flesh to its phantoms. It was not just that James's ghosts were made "real" by transferring them to the operatic stage. More problematic still, they were given words to sing. But while commentators have often admitted the ghosts' solidity, they have sought to explain them away in the same defensive spirit as Bowen's devotees. After paying lip service to the tale's notorious "ambiguity," Wilfrid Mellers went on to insist that the "modern," psychological reading of the ghosts-as inventions of the deranged protagonist-was the only sensible one. ${ }^{7}$ Nor was he the only critic to discount a more literal interpretation of the opera as a ghost story; in 1992, Philip Brett was still dismissing the opera's Gothic garb as the mere disguise with which it shrouded more "serious" concerns. ${ }^{8}$

Rather than attempting to resolve this dilemma-to determine whether The Turn of the Screw's ghosts are real or psychological, melodramatic or cerebral-I want to excavate its stakes, to ask why this distinction has mattered so much to early critics and more recent ones. For while commentators have often framed the question as a hermeneutic one, whose answer lies buried deep beneath the surface of the opera itself, their rhetoric betrays much broader aesthetic and historiographical concerns, which struck at the heart of the relationship between twentieth-century modernism and Gothic tradition.

\section{TWENTIETH-CENTURY GOTHIC}

In the long run-up to the première of Britten's opera, ghosts had become a hot topic of critical conversation. In a review from 1953 of a new ghost story collection, 
Charles Poore went so far as to diagnose a Gothic resurgence: "Don't look now, but I think we are having a flourishing revival of supernatural literature." "Newfangled ghost stories," he elaborated, "are bringing fresh terrors to the common place. Oldfangled chillers are in renewed demand." This revival included works by such well-known authors as Walter de la Mare and Elizabeth Bowen, as well as less established writers like Laurence Whistler and Rosemary Timperley. Alongside the many ghost story collections arose a growing body of criticism, which sought to legitimize and contextualize this popular wave as part of a long-standing Gothic tradition. In 1917, Dorothy Scarborough was already declaring it "impossible to understand or appreciate the supernatural in the nineteenth-century literature and that of our own day without a knowledge of the Gothic to which most of it goes back." ${ }^{\circ}$ This idea of Gothicism as a discrete, living tradition was reinforced by several book-length studies that had emerged by the mid-twentieth century, including Edith Birkhead's Tale of Terror (1921), Montague Summers's Gothic Quest (1938), and Devendra Varma's Gothic Flame (1957). ${ }^{11}$

For the most part, however, it was not such painstaking studies but broadbrush modernist attacks that set the tone for twentieth-century Gothic criticism. As Julian Petley has explained, long-term hostility toward the Gothic tradition was so heavily augmented by highbrow censure that the word "Gothic" became a term of opprobrium. ${ }^{12}$ Responding to Birkhead's study from 1921, Woolf complained that the Gothic tradition was characterized neither by coherent aesthetic theory nor by stylistic convention but by bad taste: "it is a parasite, an artificial commodity, produced half in joke in reaction against the current style, or in relief from it." ${ }^{13}$ Part of the problem was cultural belatedness-a reactionary desire to return to a superstitious, medieval past. This nostalgia often extended beyond the presence of ghosts to the setting: "Walpole, Reeve and Radcliffe," Woolf observed, "all turned their backs upon the time and plunged into the delightful obscurity of the Middle Ages, which were so much richer than the eighteenth century in castles, barons, moats, and murders." ${ }^{14}$ If the Gothic novel was already obsolete at its eighteenth-century outset, it was doubly so by the early twentieth century, at odds with the rationalizing "progress" of literary modernism. ${ }^{15}$ This cultural belatedness was matched by political obsolescence, as twentieth-century atrocities shifted horror's goalposts: "Nowadays," Woolf opined, "we breakfast upon a richer feast of horror than served them for a twelvemonth; we are tired of horror; we suspect mystery." ${ }^{16}$

A more common objection to the Gothic was its association with melodrama, as Bradenham's review of Demon Lover made clear. As Jacques Barzun suggested in his "Henry James, Melodramatist" from 1943, the term "melodrama" implied a crude moral opposition between good and evil, usually expressed in the stagiest fashion. ${ }^{17}$ By the middle decades of the twentieth century, "melodrama" had become an even more scathing moniker than "Gothic" among highbrow critics and artists. ${ }^{18}$ In putting the two aesthetic modes together, commentators alluded 
to a number of common sins. On the most basic level, they included a shared reliance on stock characters and settings. Woolf, after all, mocked "the skull-headed lady, the vampire gentleman, [and] the whole troop of monks and monsters" that peopled the Gothic novel, while Birkhead compiled a catalogue of tropes:

The Gothic Romance did not reflect real life, or reveal character ... It was full of sentimentality, and it stirred the emotions of pity and fear; the ethereal, sensitive heroine, suffering through no fault of her own, could not fail to win sympathy; the hero was pale, melancholy, and unfortunate enough to be attractive; the villain, bold and desperate in his crimes, was secretly admired as well as feared; hairbreadth escapes and wicked intrigues in castles built over beetling precipices were sufficiently outside the reader's own experience to produce a thrill. ${ }^{19}$

As Birkhead made clear, it was not merely the fact of conventionality but also the types employed that linked Gothic tradition with melodrama; theirs was a shared contrivance whereby events and characters were exaggerated in order to arouse emotions. Woolf joked that "run[ning] over the names of some of the most famous of the Gothic romancers" would elicit "smil[es] at the absurdity of the visions which they conjure up," while another critic derided Gothic novels as "tales of terror, of sentiment and sensibility, but rarely if ever of sense." 20

In its appeal to emotion instead of intellect, the Gothic offered a popular alternative to the realism and rationalism of the modern novel: "There must have been something in the trash that was appetizing, or something in the appetites that was coarse," wrote Woolf, denigrating not just the pleasures on offer but also those who enjoyed them. ${ }^{21}$ While the Gothic market had "flourished subterraneously all through the nineteenth century," it had apparently re-emerged in the twentieth century as a shameless cog in the mass cultural wheel. ${ }^{22}$ After accusing the nineteenth-century ghost story of spawning "'the unhealthy and unwholesome rubbish' that is the detective novel and thriller of to-day," another commentator went as far as to suggest that the Gothic novel "laid the foundations of circulating library popularity," as if its ghosts and ruined castles had singlehandedly galvanized mass literacy. ${ }^{23}$

Ultimately it was emerging mass technologies that proved the most popular outlet for twentieth-century Gothic melodrama. Many of those who had previously borrowed or purchased ghost story collections turned to the wireless or to cinema for their daily dose of the supernatural. ${ }^{24}$ Radio series like the BBC's Appointment with Fear, which dramatized ghost stories old and new between 1943 and 1955, were popular with listeners, but it was film that emerged as the most "avid, unashamed plagiarizer of earlier, literary forms of the Gothic," as Misha Kavka has recounted. ${ }^{25}$ Hollywood's Universal Horror films swept Britain throughout the 1930 s and 1940s, and British imitations were just as popular. ${ }^{26}$ Even before the release of the iconic "Hammer Horror" movies in the late 1950s, there existed a distinctive British tradition, every bit as melodramatic as the American original. ${ }^{27}$ 
But the tentacles of the Gothic tradition stretched far beyond the horror genre, as Ian Conrich has argued; such was the power and familiarity of Gothic codes that could add tension or suspense to a whole range of film genres, from supernatural thriller to murder mystery, comedy, or romance. ${ }^{28}$

Britten came of age during this crescendo of Gothic forms and imagery, evincing a deep interest in the supernatural from early on. In the introduction to his Simple Symphony (1934), he recalls being punished at school for "nocturnal expedition[s] to stalk ghosts," and a diary entry from 1931 records: "Fool[ing] about in [the] drawing room after dinner play[ing] 'Murder' game \& telling ghost stories-and so I am going to bed in a very suitable frame of mind!!!”29 In literature, Britten was drawn not only to nineteenth-century classics of a supernatural bent but also to the "cheaper" ghost story collections that highbrow critics loved to hate. ${ }^{30}$ One day in October 1931 saw Britten devouring an unnamed collection of ghost stories; the next August, he spent an evening engrossed in Thomas Ingoldsby's Gothic tales. ${ }^{31}$ As with most of his generation, his Gothic experience was not limited to the written word. The young composer's enthusiasm for A. J. Alan's “clever" ghost story broadcasts may have been somewhat muted, but his reaction to Rodney Ackland's dramatic adaptation of a Horace Walpole novel included melodrama of its own: "it was eerie \& frightening beyond belief-so much so that I go back to Beth's to sleep!" ${ }^{2}$ While he seems not to have seen the notorious Universal Horror films in his cinema visits throughout the 1930 s and 1940s, many of Britten's favorite films drew heavily on the tropes and techniques of Gothic cinema, whether for the purposes of satire (as in Clair's Ghost Goes West, 1936) or suspense (as in Hitchcock's Man Who Knew Too Much, 1934)..$^{33}$ When it came to trying his hand at composing for the commercial cinema, it was a Gothic melodrama-Rowland Lee's Love from a Stranger (1937) - to which Britten turned.

These early encounters left a permanent mark; from the Serenade (1943) to the Nocturne (1958), the War Requiem (1962) to Owen Wingrave (1970), ghosts and Gothic imagery suffused Britten's oeuvre. Nevertheless, most commentators agree that the most provocative of Britten's supernatural encounters came over the airwaves on the evening of June 1, 1932, as his diary reports: "listen to the Wireless . . . a wonderful, impressive but terribly eerie \& scarey [sic] play 'The Turn of the Screw' by Henry James." 34 By January 1933, Britten had read James's original novella, reporting: "Read more of James' glorious \& eerie 'Turn of the Screw" on the 6th and "Finish the 'Screw.' An incredible masterpiece" on the 7 th. ${ }^{35}$ Although Britten re-encountered the tale in America, it was apparently not until 1952-after a screening of The Tales of Hoffmann - that he thought of making an operatic adaptation. ${ }^{36}$ According to Myfanwy Piper, the opera's librettist, it was she who first put forward The Turn of the Screw as the basis for an opera-film, one with which the English Opera Group might surpass Powell and Pressburger's spectacular creation. ${ }^{37}$ In the end, however, it was an altogether different venture that saw James's novella pressed into service: the fulfillment of a joint commission-by the 
Venice Biennale and the 27th International Festival of Contemporary Music-of a live opera, not a film, to be staged at Teatro La Fenice on September $14,1954 \cdot{ }^{38}$

\section{THE TURN OF THE SCREW AND GOTHIC MELODRAMA}

In fashioning the plot of their opera, Britten and Piper stuck relatively close to James's original. It revolves around a young and innocent Governess, who is employed to care for a pair of orphans (Flora and Miles) at their isolated countryside estate. After a promising start, the Governess begins to encounter the ghostly reincarnations of a former governess (Miss Jessel) and valet (Peter Quint), who have returned to corrupt the children's innocence in ways that are not entirely clear. While most of her time is spent trying to extract information from the reticent housekeeper (Mrs. Grose), the action peaks with a series of confrontations between the protagonist and the undead intruders. By far the most melodramatic one comes in the final scene, in which the Governess incites Miles to renounce Quint, but only_it becomes apparent-at the cost of his own life. On the most literal level of the plot, then, The Turn of the Screw was deeply implicated in Gothic traditions. From its mysterious apparitions to demonic possessions and dramatic exorcisms, here was an opera essentially "about" ghosts: "ghosts are no innovation in opera," Erwin Stein admitted, "but I do not remember one in which ghosts play a principal part." ${ }^{39}$

It is not surprising, then, that many critics were squeamish about the subject. With the exception of one superstitious critic who observed gleefully that "the garish opera house . . . seemed to be covered by a ghostly light," first reactions to Piper's libretto read like a catalogue of contemporary objections to the genre. One sticking point was its morbidity: "In this absurd struggle between the spirits, the children and [the Governess]," Luigi Pestalozza complained, "there is no final salvation." ${ }^{40}$ According to another, "reservations [were] expressed by most reviewers on the subject of the libretto. Though the libretto itself appeared to them quite good, the subject, they thought, was complicated and morbid." ${ }^{11}$ For most, however, the whimsical superstition was the problem. ${ }^{42}$ As one critic warned that "skeptics" would "fail to attain the suspension of disbelief necessary for the enjoyment of a ghost story," another offered a telling anecdote: "An Italian lady in the Fenice theatre at Venice at the first performance of The Turn of the Screw was heard to ask whether Mr. Britten was an Englishman, for surely it was only Irishmen or such whimsical Celts who believed in ghosts." ${ }^{43}$ When returning to his own voice, the critic proposed: "the imagination and the intellect are reverse and obverse of the same coin and cannot, therefore, both be uppermost at the same time. Mr. Britten's imagination[,] at any rate, accepts Henry James's story and its ghosts, whatever his intellect may say to their existence."

The mise-en-scène solidified the Gothic connection. As Misha Kavka put it, "there is something peculiarly visual about the Gothic." ${ }^{44}$ Ever since the 
mid-eighteenth century, Gothic novelists and artists had relied on the symbolic potential of setting to heighten suspense. James's Screw remained faithful to this tradition: the first chapter is almost entirely devoted to describing Bly's country estate, from the "broad, clear front" and "cloistered tree-tops" on the outside, to the dull corridors and crooked staircases inside. This visual imagery no doubt appealed to the opera's creators. Both Piper and Britten turned to scenic locations- "The Tower and the Lake" - when selecting a provisional title. ${ }^{45}$

Tower and lake were also Gothic stereotypes, perfectly emblematic of the production at large. In translating James's densely descriptive prose into an actual stage design, Basil Coleman (the producer) and John Piper (the designer) magnified the novella's Gothic imagery. "The action," we are instructed, "takes place at Bly, a country house, about the middle of the last century." ${ }^{6}$ When Piper's set was unveiled, however, audiences could be forgiven for thinking they had stumbled into a ruined medieval castle. While the exterior spaces (see Fig. 5) were adorned with Gothic details-from pointed arches and turreted rooftops, to imposing tombstones and shadowy branches-the domestic interior emphasized darkness and decay. Other visual tropes to which Coleman and Piper appealed-the "spiral staircase" (Fig. 6) and the "face at the window" (Fig. 7)-were so deeply enmeshed in Gothic tradition that they had served as the titles of well-known horror films. ${ }^{47}$

These visual clichés proved less embarrassing than the work's story line. With the exception of Virgil Thomson, who found the "Victorian Gothic" imagery neither apt nor convincing, most critics were wholeheartedly enthusiastic about the set designs..$^{8}$ One critic praised the "momentary shiver $[\mathrm{s}]$ " that the backdrops sent down his spine, while another enthused: "John Piper has captured the phantasmagorical atmosphere of Bly, with its turreted towers, dream-like decors which, partially dissolving into each other, contribute to that sense of ambiguity and flux which characterizes the story." 49

The appearance of the ghosts on stage was another matter, making critics nervous from the very beginning. The flagrant materiality of opera, many suggested, could only simplify the subtle psychology of James's masterpiece and coarsen its famously "ambiguous" symbols. ${ }^{50}$ It was doubtless this sort of criticism that compelled Piper to claim, twenty-five years later, that it was not the "action" but, rather, the "words between the action" that drew her and Britten to James's Screw. ${ }^{51}$ Contrasting her libretto with William Archibald's Innocents, a stage adaptation of the same novella from 1950, Piper purported to have abjured melodrama, capturing instead the original "sense of time passing, the shifting of places, the gaps in the action, the long months when nothing and everything happened." ${ }_{52}$ "Dramatic" events in James's novella are indeed relatively few and far between. In the first half particularly, weeks and months go by without incident, with characters simply going about their daily business in the domestic setting. In crafting their scenes, Britten and Piper retained some of the ostensibly trivial details and descriptions with which James had filled his pages. While Archibald's play omitted James's 


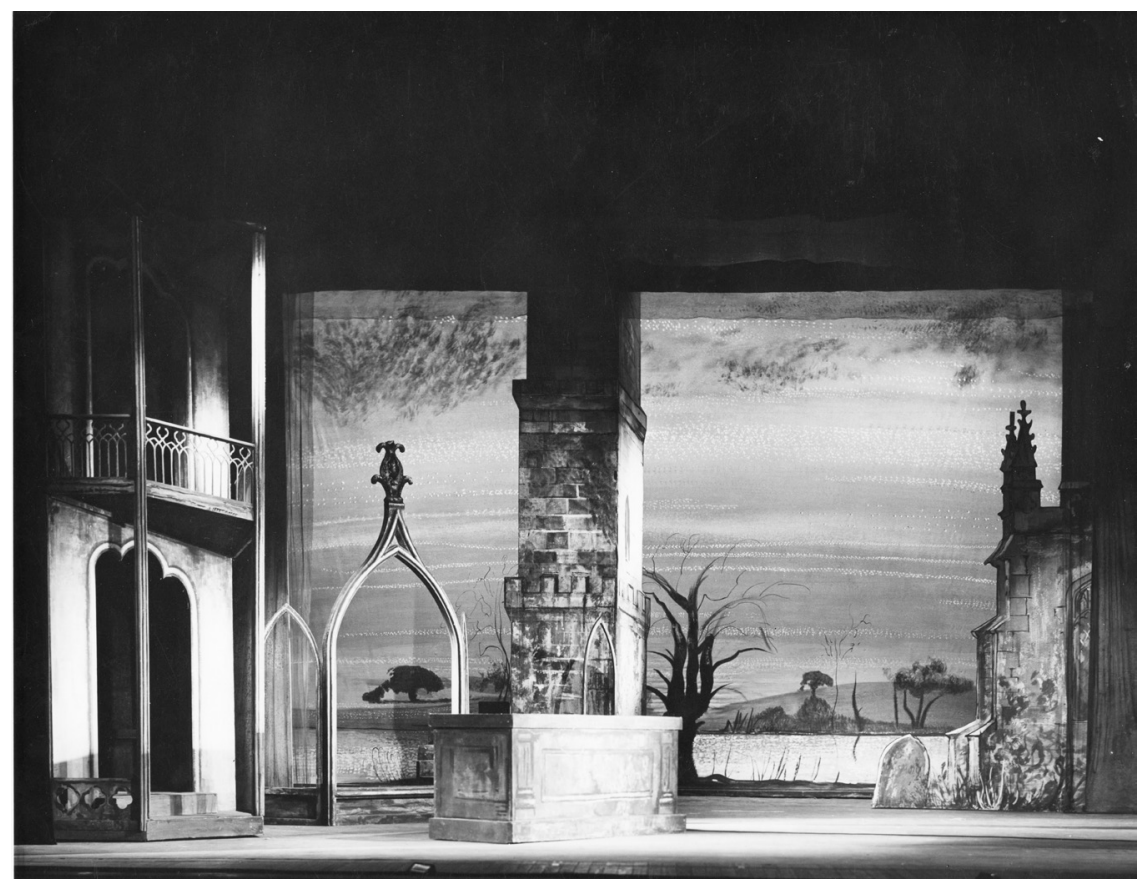

FIG. 5. Production Photograph of The Turn of the Screw, 1954: Act 2, Scenes 1 and 2. Photographer: Angus McBean. (c) Harvard Theatre Collection, Harvard University. Image courtesy of the Britten-Pears Foundation.

"bumping swinging coach" journey completely, Britten and Piper expanded it to fill the opening scene:

THE JOURNEY

[The lights go up on the interior of a coach. The Governess is in a traveling dress]

GOVERNESS

Nearly there.

Very soon I shall know, I shall know what's in store for me.

Who will greet me? The ... children ... the children.

Will they be clever? Will they like me?

Poor babies, no father, no mother. But I shall love them as I love my own, all my dear ones left at home, so far away-and so different.

If things go wrong, what shall I do? Who can I ask, with none of my kind to talk to? Only the old housekeeper, how will she welcome me? I must not write to their guardian, that is the hardest part of all. Whatever happens, it is I, I must decide.

A strange world for a stranger's sake. O why did I come? 


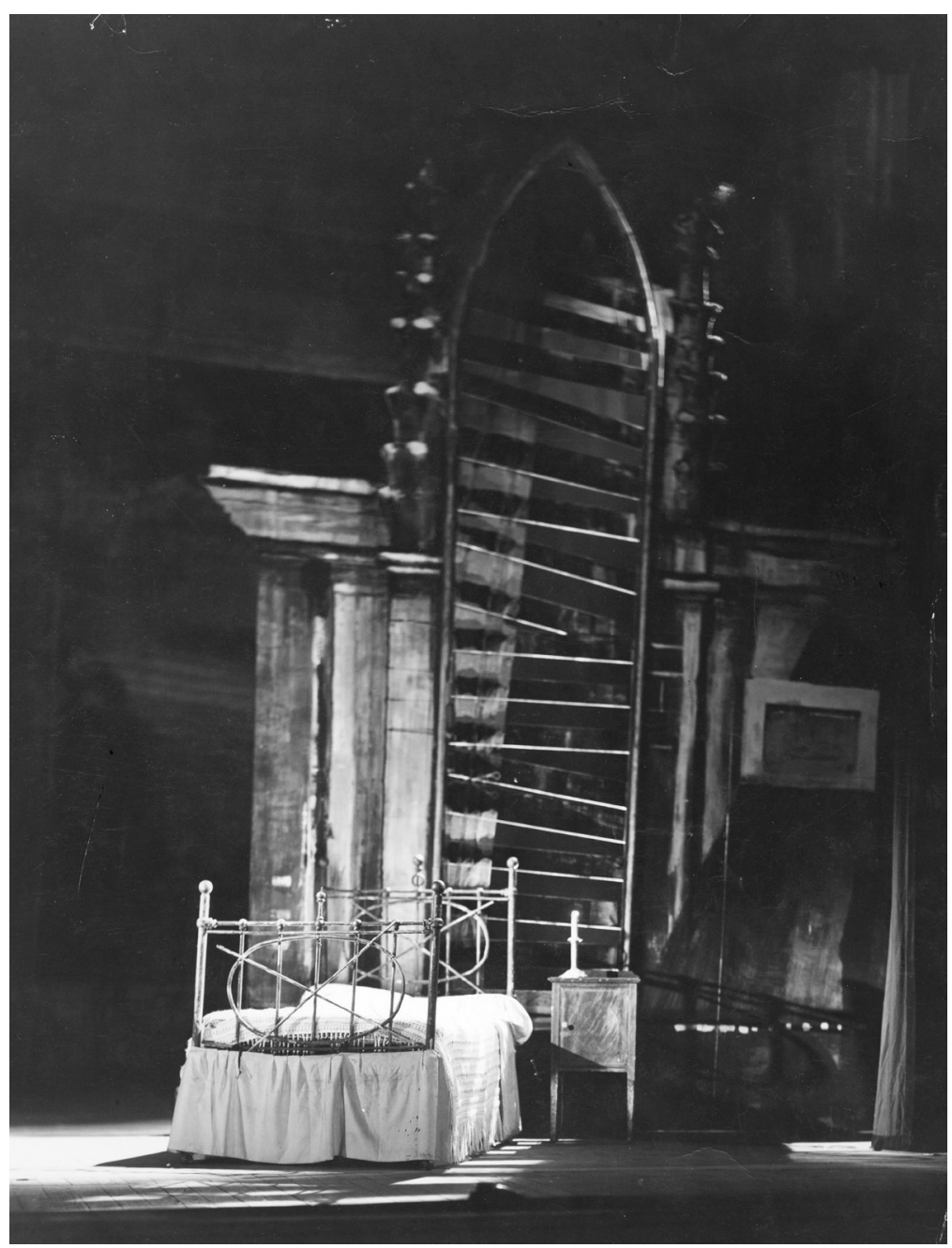

FIG. 6. Production photograph of The Turn of the Screw, 1954: Act 2, Scenes 4 and 5. Photographer: Angus McBean. @ Harvard Theatre Collection, Harvard University. Image courtesy of the Britten-Pears Foundation.

No! I've said I will do it, and-for him I will. There's nothing to fear. What could go wrong? Be brave, be brave. We're nearly there. Very soon I shall know. Very soon I shall know. ${ }^{53}$

Journeys in opera usually happen between scenes, with characters having already arrived by the time the curtain rises. But far from inducing yawns, this uneventful episode is freighted with sinister foreboding. Combining cryptic questions 


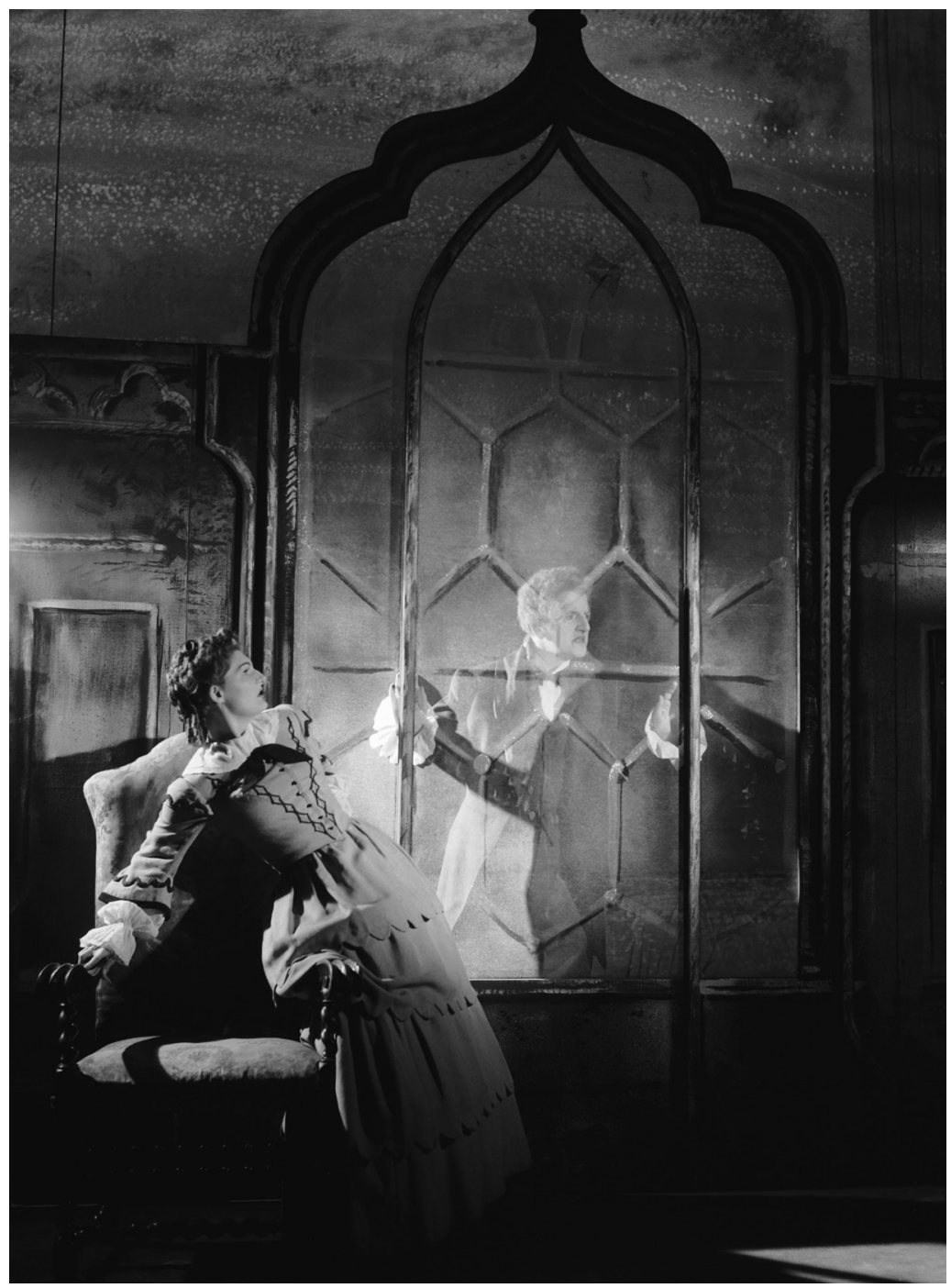

FIG. 7. Production Photograph of The Turn of the Screw, 1954: Act 1, Scene 5. Photographer: Denis de Marney. Copyright: Getty Images.

with rhetorical excess, Piper instills her text with a sense of mystery and suspense, heightened by Britten's musical atmospheres.

Yet even after conceding that "for the theatre, Myfanwy Piper had no choice but to fill in, even to elaborate, what James surely deliberately left unexpressed in the nature of the ghosts," Martin Cooper could still complain that "They appear too often in this foreshortened version and say too much to maintain the effect of what 
should be nameless horror." ${ }^{54}$ While Britten and Piper curtailed the Governess's monologues, they increased the frequency of the ghostly apparitions, and gave the originally silent ghosts words to sing. Even sympathetic critics were perturbed: "It is obvious that in the opera they would have to speak," conceded Massimo Mila, "but one sometimes one feels that they speak too much, that they are very talkative ghosts." ${ }_{55}$

While Quint's “possession” of Miles was merely implied by James's original protagonist-narrator, it is given strikingly literal representation in the opera's tension-filled encounters. Toward the middle of the second act, we see Quint poised theatrically over Miles (see Fig. 8), directing his movement by pointing and goading him to steal the Governess's letter: “Take it! Take it! Take!” While one commentator defended the scene as "very well done," others bemoaned its naïve and "literal-minded" take..$^{56}$ An even more pantomimic staging of this underlying theme comes at the end of the opera, where the Governess's metaphorical battle with Quint over the young boy's soul is staged literally (see Fig. 9), each character tugging on one of Miles's outstretched arms. If melodrama was said to thrive on an overly simplistic moral code-a worldview in which right and wrong, good and evil, were easily distinguishable - then this dramatic tug of war, between villainy and virtue, would appear to be its epitome. One critic blamed the composer for turning James's story "into a morality play, a struggle of Good . . . and Evil for the children's souls," while others chalked the melodramatic conclusion up to downstage positioning and exaggerated acting: "Objections would largely vanish if the production were more careful to keep the ghosts far back on stage and dimly lit." 57

Two scenes were not so easily redeemable. Even if Peter Pears had stood further back on stage and donned "a more plausible red wig," Shawe-Taylor joked, the last scene of Act I and the first scene of Act II would still have raised eyebrows..$^{58}$ As the scenes in which the ghosts were given extended passages of song, they of course departed radically from the original. But critics voiced misgivings not just about fidelity but also about their poor taste, especially when it came to the libretto's obviousness and rhetorical excess. Attempting to represent the unrepresentableto distill the "nameless horror" of the supernatural into words-Piper adorned the ghosts's speech with gaudy verse:

QUINT

I am all things strange and bold,

The riderless horse

Snorting and stamping on the hard sea sand, The hero-highwayman plundering the land. I am King Midas with gold in his hand.

MILES

Gold, O yes, gold! 


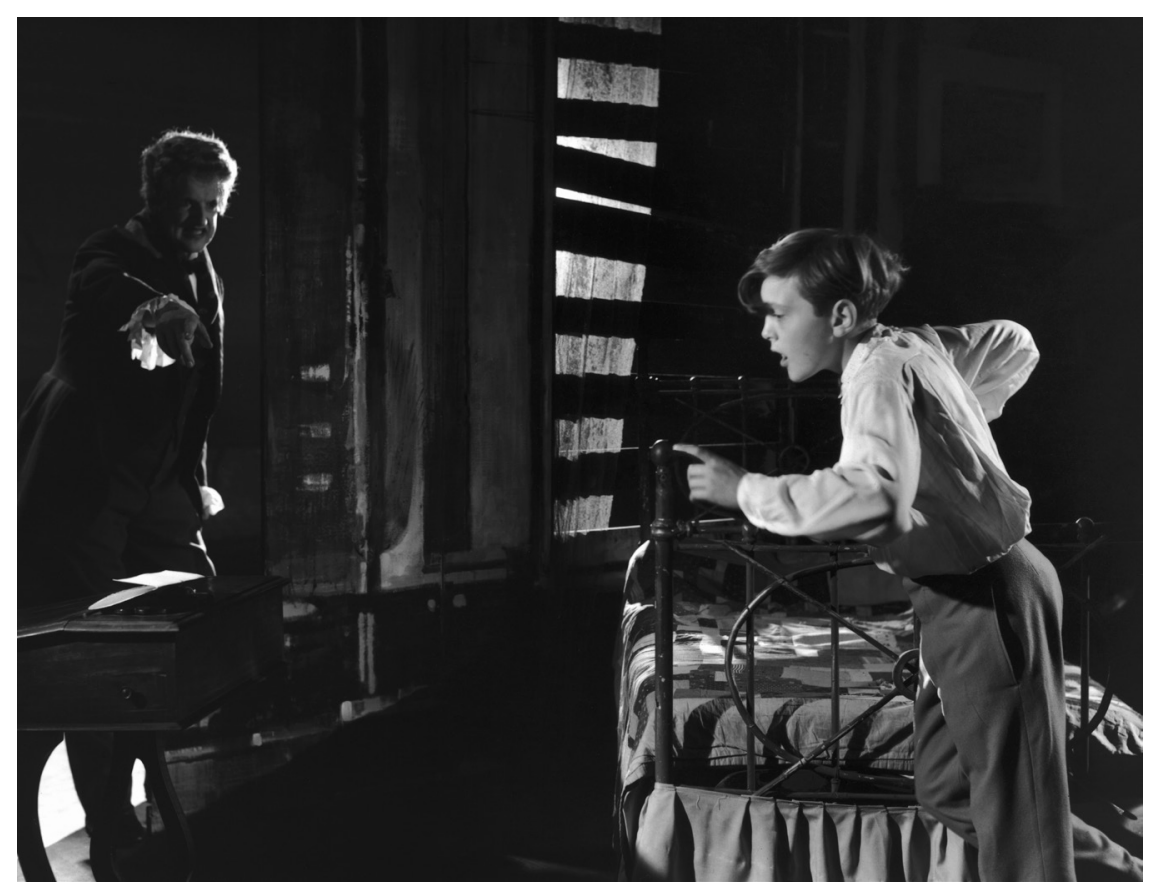

FIG. 8. Production Photograph of The Turn of the Screw, 1954: Act 2, Scene 5. Photographer: Denis de Marney. Copyright: Getty Images.

\section{QUINT}

I am the smooth world's double face,

Mercury's heels

Feathered with mischief and a god's deceit.

The brittle blandishment of counterfeit.

In me secrets and half-formed desires meet.

MILES

Secrets, O secrets!

QUINT

I am the hidden life that stirs

When the candle is out;

Upstairs and down, the footsteps barely heard.

The unknown gesture, the soft, persistent word,

The unknowing gesture, the soft, persistent word,

The long sighing flight of the night-winged bird. ${ }^{59}$

Early audiences were left scratching their heads at this string of Gothic clichés and mythological allusions: "The last scene in Act I," Colin Mason complained, "is 


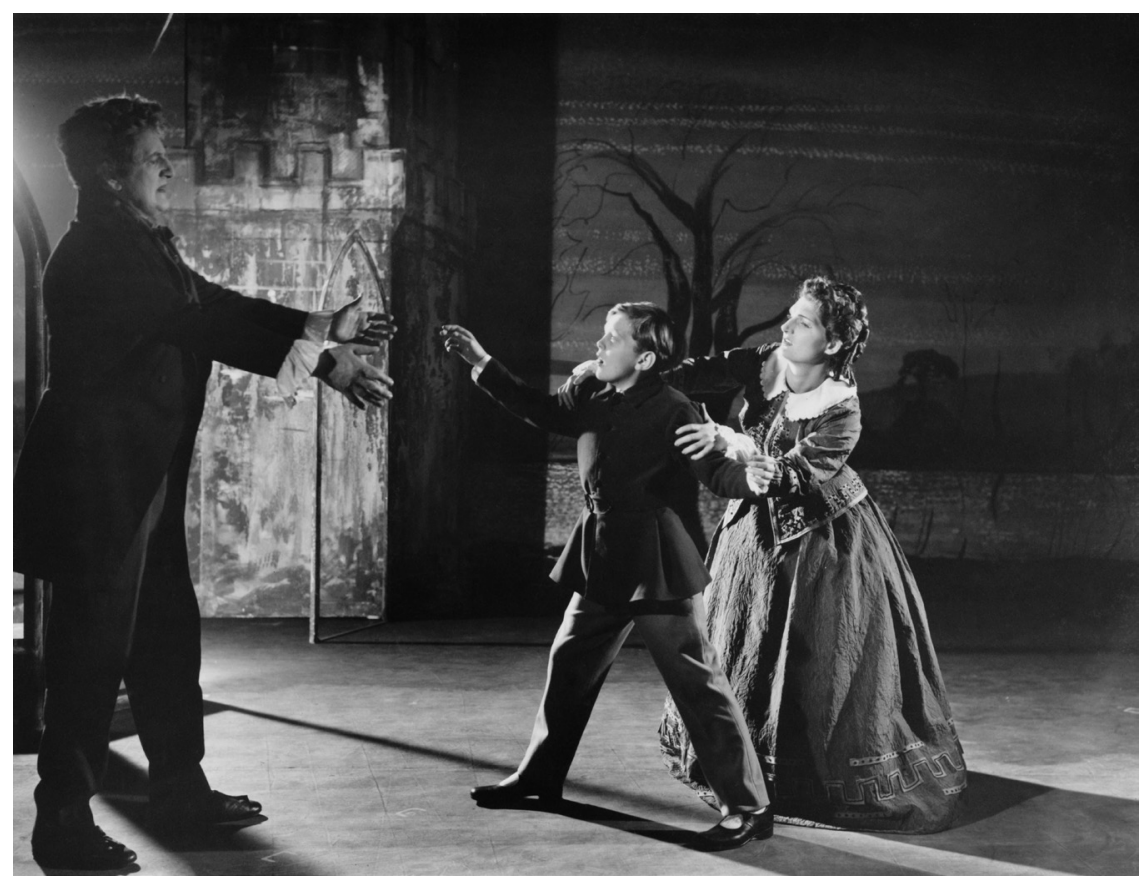

FIG. 9. Production Photograph of The Turn of the Screw, 1954: Act 2, Scene 8. Photographer: Denis de Marney. Copyright: Getty Images.

expanded into a quartet in which the relationship between the children and the ghosts is made crudely explicit, and yet no more intelligible." ${ }^{\circ 0}$ While one critic appreciated the scene's "melodramatic pathos," others saw it as having fallen flat on its face: "Quint's stanzas . . . faintly reminiscent of Midir's Luring Song in The Immortal Hour, are quite too harmless for a devil whose utterances ought almost to scare the Lord Chamberlain. And the music, at this point[,] cannot supply (what music could?) the evil element missing in the words." ${ }^{1}$

The second of the two scenes, the "Colloquy and Soliloquy," which opens the second act, was plagued by similar problems. While the Night Scene had merely introduced words to an existing scenario, the Act II duet is entirely new: a lovers' quarrel between the two ghosts. After Miss Jessel accuses of Quint of having betrayed her love, he replies that it was her own passions that deceived her, before reenacting his betrayal all over again:

QUINT

I seek a friend.

MISS JESSEL

She is here! 
QUINT

No!-Self-deceiver.

MISS JESSEL

Ah! Quint, Quint, do you forget?

QUINT

I seek a friend-

Obedient to follow where I lead,

Slick as a juggler's mate to catch my thought,

Proud, curious, agile, he shall feed

My mounting power.

Then to his bright subservience I'll expound

The desperate passions of a haunted heart,

And in that hour

"The ceremony of innocence is drowned."

MISS JESSEL

I too must have a soul to share my woe

Despised, betrayed, unwanted she must go

Forever to my joyless spirit bound

"The ceremony of innocence is drowned."

QUINT AND MISS JESSEL

Day by day the bars we break,

Break the love that laps them round,

Cheat the careful watching eyes,

"The ceremony of innocence is drowned."

"The ceremony of innocence is drowned."62

Toward the end of their colloquy, Quint spurns the renewed advances of Miss Jessel, preferring a "curious" and "agile" friend (Miles). Together they vow to pursue the young children to satisfy their own selfish needs-Quint, the need for power, and Miss Jessel, the need to share her woe-as they come together in the climactic refrain, famously borrowed from Yeats's "The Second Coming."

For a number of commentators, the scene took theatrical explicitness to an even less acceptable level, having the ghosts act out a supposedly mysterious past in such summary fashion. One writer mocked the dialogue as "perhaps a little obvious," before complaining that the "first scene of the second act, where the two ghosts sing of their private affairs left me rather puzzled... One has the impression that both the composer and the librettist have condensed into this scene all the explanations and the symbolic ideas of the work." ${ }^{3}$ Others viewed the meeting as a pretext for more melodrama; while one critic lamented that "they open[ed] the second act with a melodramatic scene during which [the ghosts] proclaim their evil aims," another denounced the scene, "in which Quint and Miss Jessel behave like two solid stage villains," as an "unnecessary inclusion." ${ }^{64}$ It was not just the 
morbid preoccupation with evil that reeked of melodrama. That the librettist had added yet another dramatic conflict to an already creaky plot, one wrote, "makes too big a demand on our ordinary theatrical credulity."65

\section{MODERN GHOSTS}

Not that the opera was poorly received. On the contrary, most accounts of the premiere began with reports of rapturous applause: "the audience politely brought the fine English cast back for eight curtain calls," noted one commentator. ${ }^{66}$ This enthusiasm was apparently shared by critics and commentators from all over Europe. The director of La Fenice described the occasion as "one of the great nights of our historic Venetian theatre," while the London Times critic dubbed the opera "masterly" ${ }^{67}$ The reaction was especially significant, for, as commentators were keen to point out, the Venice Biennale had become one of the leading showcases of contemporary European opera. Invoking a list of recently performed works, several critics cast The Turn of Screw as Britain's answer to The Rake's Progress and Lady Macbeth of the Mtsensk District. Its combination of "refined music" and "obscure Jamesian plot," they agreed, advanced the cause of new opera. ${ }^{68}$ When the English Opera Group's production returned home to Sadler's Wells, it was cast as a victory lap in the British press. ${ }^{69}$

Commentators were, however, only too aware that the opera's supposedly sophisticated style fitted oddly with the melodramatic features to which they occasionally alluded. For this reason, they tended to describe those features as exceptions that proved the rule: an atavism that only highlighted the Screw's distance from Gothicism proper. After noting the crude explicitness of the two "problem" scenes, one commentator pushed them aside: "From this single flaw, which could quite easily be removed, it is a pleasure to turn to the extraordinary virtues of [the] text." "o "These calculated misjudgments, however," another critic agreed, "do little to mar the theatrical effectiveness of the piece."71 Virgil Thomson went even further, disavowing the "misjudgments" entirely:

In this work the numerous faults of dramatic taste that have weakened the punch of [Britten's] recent operas seem to me almost wholly absent. On the contrary, two changes in the Henry James story were bold and are, I think, advantageous, though either could have changed the whole tone and meaning of it had they not been done with a sure hand ... The turning of James' furtive and silent ghosts into overtly-singing ones ... risked making of the establishment a banal "haunted house," of which there are thousands in the world ... That they did not vitiate the terror of the tale is proof of somebody's sound literary sense. ${ }^{72}$

While most commentators stopped short of such unequivocal denial, they invoked the same rhetoric of overriding fidelity. For each one who lamented that "what Myfanwy Piper has done with [the story] takes it quite out of the Jamesian sphere," there was another who emphasized absolute fidelity to the opera's source..$^{73}$ 
After admitting that Piper had "occasionally been insensitive to some of Henry James' silences and reticences," another nevertheless insisted: "she has been very faithful to the original." 74 Never mere factual observations, such statements were marshaled in aesthetic defense, as Desmond Shawe-Taylor's response makes clear: "Practical disadvantages, however regrettable, must not obscure the aesthetic issue - the unquestionable truth, as it seems to me, that . . the little opera is a consummate work of art: a work of art in quite the high sense of James himself." 75 Invoking James in this way, commentators could make Britten the beneficiary of some high-profile struggles over the Jamesian legacy, particularly the author's status as a forefather of twentieth-century modernism. ${ }^{76}$

Defending James's oeuvre from Jacques Barzun's provocative "Henry James, Melodramatist," Q. D. Leavis had, for example, stressed the subtle detail and ironic detachment of his novella. ${ }^{77}$ The opera's defenders were just as keen to stress these aspects. After observing that "the 'curious story' that the Prologue promises has even as an opera preserved the character of a narrative," one critic elaborated: "Neither the immediacy of the stage nor the emotional directness of music has excluded a certain detachedness of approach."78 Another critic, writing for the Italian press, went so far as to praise the opera for "bring[ing] back the subtle agony of James," demonstrating "nobility of style and detachment from overt and simple complicity with the salacious subject." ${ }^{79}$

Another defense borrowed from Jamesian criticism was that of hermeneutic ambiguity. Gothicism and melodrama being associated with an uncomplicated binary worldview, praising "obscurity" or "ambiguity" was an easy means of steering the opposite way. Indeed, commentators were surprisingly keen to stress their own bafflement at what was otherwise a relatively straightforward haunted house tale. While one admitted, "It is very difficult to establish even approximately what The Turn of the Screw. . . was supposed to mean," another asked: "What should an Italian audience make of a sung version in the original language of a story which English readers have been reading for years without ever really finding out what it means?"80 Such bafflement could only imply praise at a time when "ambiguity" was a mark of distinction, implying complexity and richness of meaning on the part of the work, and intelligence on the part of its interpreters. ${ }^{81}$ Of this, the first-night audience appears to have been all too aware, reportedly falling over themselves to demonstrate that they could rise to the "ambiguous" tale's challenge: "Unlike the French at 'Billy Budd," one commentator explained, "[this audience was] not unresponsive. Clearly their practice in Pirandello stood them in good stead, and they fell outside into dozens of little groups gamely, ingenuously, or obscurely explaining and counter-explaining, and all ready to die rather than look blank." 82

Such an emphasis was a central part of the novella's mid-century reception too, set out most famously in Edmund Wilson's essay of 1938, “The Ambiguity of Henry James." The real horror behind the story line's "ostensible" one, Wilson suggested, 
was that the novella's devotees had missed its deeper meaning. Following the work of Edna Kenton and Charles Demuth, he argued that the story's ghosts were best understood as products of the protagonist's imagination. His Freudian reading cast the novella as a tale of psychological delusion and sexual repression, rather than a supernatural thriller in the Gothic mold: "The poltergeist, once a figure of demonology, is now a recognized neurotic type." ${ }^{83}$ For all Wilson's loudly trumpeted talk of "ambiguity," in other words, he appears rather confident of the story's meaning, sternly refusing to read it as a ghost story. ${ }^{84} \mathrm{~A}$ number of the opera's critics appear to have picked up this kind of critical doublethink, championing ambiguity in one breath, explaining it away in the next. While one review praised the opera as a lodestar of a "new psychological aesthetic," another was titled "Governess as Ghost": "Both the libretto by Myfanwy Piper and the composer's musical treatment of it seem to have opted for that theory of the tale in which the ghosts are an invention of the Governess." 85

These defenses were not without foundation. James was arguably in on the interpretive game, encouraging critics to disregard some of his novella's most striking features and influences. On the most basic level, the story often draws self-conscious or ironic attention to its own Gothic conventions, thereby subtly discrediting them as interpretive frameworks. After encountering Quint for the first time in chapter 3, James's Governess appears to mock her own gullibility while parodying Gothic convention: "Was there a 'secret' at Bly-a mystery of Udolpho or an insane, unmentionable relative kept in an unsuspected confinement?"86 Elsewhere, she casts even greater aspersions on the Gothic clichés: "[Miles] could do what he liked ... so long as I should continue to defer to the old tradition of the criminality of those caretakers of the young." ${ }^{87}$ While these particular references were not retained in the opera, Piper's libretto found comparable means of throwing audiences off the Gothic scent. At the start of the fourth scene, the Governess parodies her own susceptibility to Gothic cliché: "My foolish fears are all vanished now, are all / banished now / those fluttering fears when I could not forget the letter / when I heard a far off cry in the night / and once a faint footstep passed my door." ${ }^{88}$ Later on, immediately after the controversial Act 2 Colloquy, the Governess devotes an entire monologue to imaginative delusion:

GOVERNESS

[The lights fade out on Quint and Miss Jessel and fade in on the Governess]

Lost in my labyrinth I see no truth

Only the foggy walls of evil press upon me.

Lost in my labyrinth I see no truth.

O innocence, you have corrupted me, which way shall I turn?

I know nothing of evil yet I feel it, I fear it, worse-imagine it.

Lost in my labyrinth which way shall I turn? ${ }^{89}$ 
Thus, no sooner had the opera manifested its ghosts in a stagey, domestic quarrel than it moved to dematerialize them, using both text and lighting to reinterpret the Colloquy as a product of the Governess's imagination. While the opera's audience cannot actually witness events through the eyes and ears of the Governess, as in James's novella, it is nevertheless encouraged to identify with her and share her interpretative dilemmas. She is, in other words, cast as the symbolic spectator. This sense of the Governess mediating the narrative, even though she is not the narrator, is heightened by the opera's prologue, which casts the work as a retelling of testimony "written in faded ink, a woman's hand, governess to two children, long ago." ${ }^{90}$

Nor is it just the Governess who casts doubt on her testimony. The other characters also have inconsistent faith in the Governess and ghosts. While she alone witnesses Quint's first appearance on the tower in scene four, her detailed description appears to be enough to convince Mrs. Grose that the former valet had indeed come back to life. By the second-act lake scene, however, Mrs. Grose has changed her mind, unable to see the ghost standing right beside her: "Indeed Miss," she insists, "there's nothing there." ${ }^{91}$ Yet such incredulity does not last; by the beginning of the following scene, she mysteriously repents and reaffirms her faith in the Governess's visions. The children's position is even more contradictory. Much ink has been spilled trying to determine the extent of their knowledge of (and complicity with) the opera's ghosts. On the one hand, we witness Flora and Miles conversing with Miss Jessel and Quint respectively (as, for example, in Act I, Scene 8). On the other hand, they often appear completely ignorant of the ghosts, even charging the Governess with imagining them:

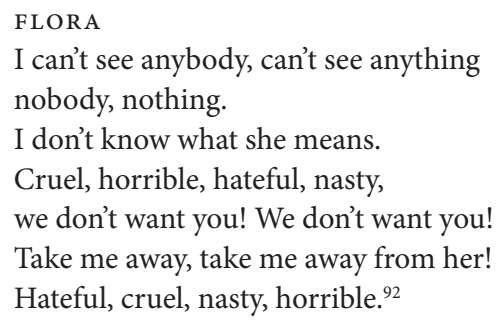

Throughout both the novella and its operatic adaptation, there are frequent attempts to pathologize the protagonist, raising questions about her sanity and her testimony. As commentators have often pointed out, the novella's long and complicated prologue introduces the Governess as a "fluttered, anxious girl out of a Hampshire vicarage," whose sexual repression and inexperience engender an infatuation with her prospective employer. For Wilfrid Mellers, this was proof enough of psychological subtext: "since there never was a less adventitious writer than James, I find it difficult to credit that, were not the Freudian interpretation basic, he would have stressed the Governess's infatuation for the Guardian, who 
is presented as a figure of unattainable sexual glamour." ${ }^{93}$ When Britten and Piper finally decided to have a prologue of their own, it was this detail that they placed at its center: "She was full of doubts / But she was carried away: that he, so gallant and handsome / so deep in the busy world, should need her help."94 This infatuation reappears throughout the opera, particularly in connection with the ghostly encounters. In the tower scene (Act I, Scene 4), for example, the Governess longs to see her employer immediately before Quint appears:

GOVERNESS

Only one thing I wish, that I could see himand that he could see how well I do his bidding.

The birds fly home to these great trees, I too am at home.

Alone, tranquil, serene.

[Quint becomes visible on the tower.]

Ha! 'Tis he!

[He looks steadily at her, then turns and disappears]

No! No! Who is it? Who?

Who can it be? ${ }^{25}$

Combining signs of sexual longing with expressions of isolation, the scene encouraged audiences to don psychoanalytic spectacles. Critics were only too happy to take the bait, steering the opera away from the Gothic mold into a more modern, psychological thriller. In wielding psychology against Gothic melodrama, however, these critics were not as modern as they may have thought. The tension between physical and psychological terror, reality and fantasy, had been endemic to the Gothic genre from the start, and was still at play in the most popular Gothic tales of the early- and mid-twentieth century. ${ }^{96}$

\section{GOTHIC MUSIC}

None of these discussions about the opera's ambivalent relationship with modernism and Gothic melodrama would have been so fraught had they not had significant implications for the music. Opera was regarded as a musical genre first and foremost, and it was Britten's integrity and legacy that critics were most concerned to protect. It was for this reason that they often tried to separate the music from other operatic components. Even Ernest Newman, who dismissed the libretto because "what Myfanwy Piper has done with it takes it quite out of the true Jamesian sphere," defended Britten's music to the hilt: "But when we come to consider the music there would seem to be a different story to tell." ${ }^{\prime 97}$ The music supposedly did not partake of Gothic melodrama's crude tricks, and commentators devoted considerable energy to directing the audience's attention toward its more cerebral—even modernist—aspects. 
One of these was the opera's widely publicized gestures toward musical formalism, particularly serialism. As a number of critics and analysts pointed out even before the premiere, the principal "theme" - first introduced after the prologueincluded all twelve notes of the chromatic scale. ${ }^{98}$ This theme became the basis for a protracted theme-and-variations structure, stretching across the entire opera's scenes and interludes, which expands upon the opening theme. Furthermore, as one critic pointed out, each interlude fixes the key of the following scene in ways that foreground even greater structural and symmetrical logic: "The sequence of key rises in the first act and descends in the second."99 "Although each key has its own mood and colour," the same critic continued, "a unifying thread runs through the ritornelli." ${ }^{100}$

As this response makes clear, it was not just symmetry but unity that the opera's critics were touting. Indeed, the idea of an underlying motivic unity beneath the musical surface-a common means of stressing formal integrity and warding off charges of eclecticism-was a central trope in the opera's reception. After admitting that Britten's "use of the note row is also very free," one critic equivocated: "although it would not be an exaggeration to say that the entire opera is based on it." ${ }^{101}$ Stein concurred: "almost the entire music of the opera is based on only two themes." 102 The combined effect of this motivic unity and variation technique, he concluded, was to provide large-scale formal coherence to a seemingly episodic structure. Elsewhere, Stein was even more candid in suggesting that listeners hear musical unity rather than melodramatic eclecticism:

The themes of the opera are closely related with each other, not in character, but by the motives of which they consist. They are derived chiefly by way of variations from the theme of the screw. It so happens that a child's song and ghost's incantation occasionally use similar melodic turns. ${ }^{103}$

Occasionally, critics resorted to stronger rhetoric, discrediting surface stylistic heterogeneity entirely: "It sounds on first hearing improvised and facile, casual and only superficially brilliant. But it is not. It is, in fact, rather elaborately constructed out of well-chosen themes and formal variations on them." ${ }^{104}$ Other commentators - no less defensively_invoked comparisons with "purely" instrumental genres as a means of stressing the primacy of musical form. One insisted that the music "stands on its own every bit as firmly as a symphony or a set of variations," while another concluded: "Britten can also let music take charge of a whole situation, music that is not just interesting for its dramatic values, but strikingly compelling in a purely symphonic kind of way." ${ }^{105}$ This trope of musical purity, unspoiled by dramatic or illustrative considerations, also came out when a critic enthused that James's prose had proven "stimulating to the composer's purely musical instinct." ${ }^{106}$ One critic even went so far as to subtitle his review "masterly construction," while yet another described the whole work as "the most difficult and tightly unified of Britten's operas." 

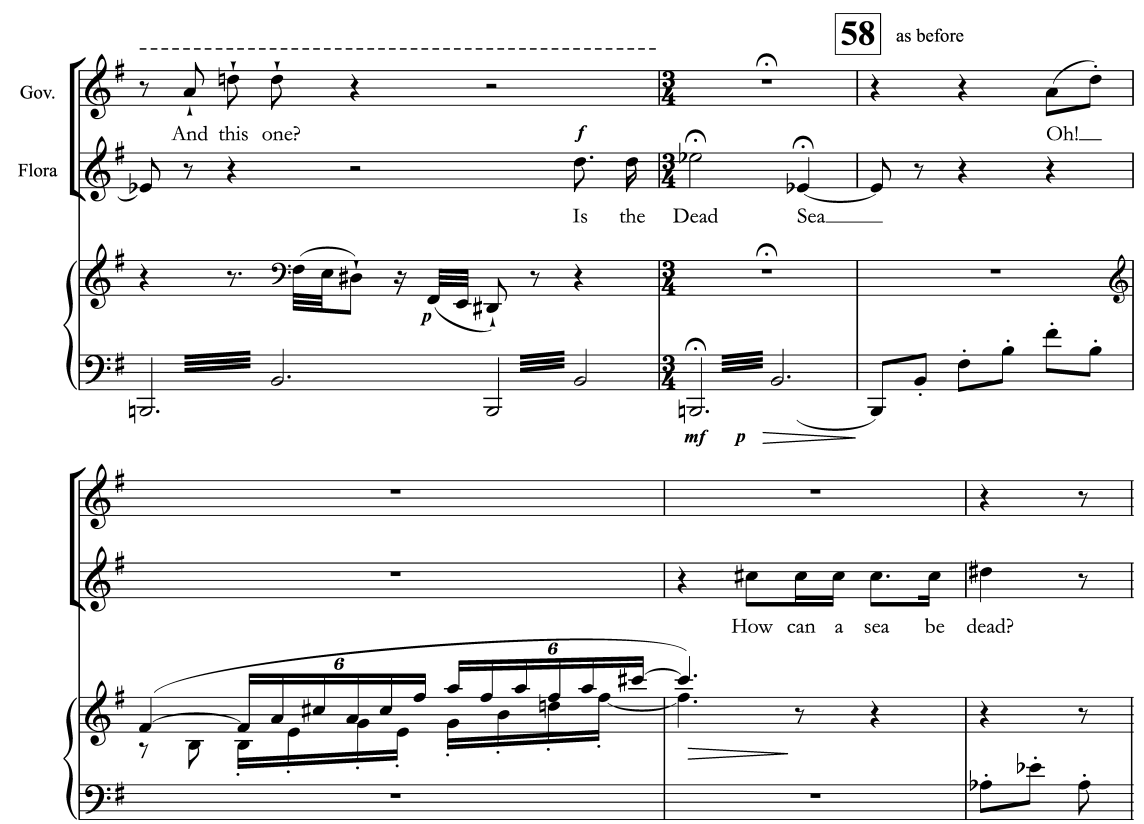

Ex. 13. The Turn of the Screw (Act I, Scene 7)_-“The Dead Sea”.

This focus on "purely musical" matters of form, unity, and symmetry provided a musical equivalent to the libretto's psychoanalytic perspectives. ${ }^{108}$ But like the opera's textual codes and ciphers, these musical clues were neither well hidden nor particularly consistent. As Philip Rupprecht has observed, although the "screw" theme's claustrophobic ubiquity seems to endow it with even greater power and agency than a Wagnerian leitmotif, it lacks a Wagnerian sense of physical or metaphysical reference: "its function is not tied to specific elements of plot or character, but to the way in which these are presented to the audience; the Screw is less a part of the story than of its telling." ${ }^{109}$ One might even think of the opera's formal patterns and connections as a kind of Gothic game-a Radcliffean secret, in which underlying meaning and logic is constantly toyed with, and just as constantly undermined.

Yet, with only a few telling exceptions, Britten's music outside the interludes eschews extended musical forms and set pieces in favor of a more fluid, musically enhanced declamation, halfway between recitative and aria. When some critics described the vocal writing as melodramatic, they meant it as much in a historical sense-harking back to a nineteenth-century recitation with heightened musical accompaniment-as in an aesthetic one. ${ }^{110}$ When Flora interrupts her song of the seas (see Ex. 13) and fixates upon the "Dead Sea" with macabre obsession, Britten 
almost brings musical time to a standstill as he repeats the sinister half-step interval with relative abandon. In the controversial Act II Colloquy (Ex. 14), the flexible vocal lines veer between the speech-like monotone of the opening measures and the hysterical screams of "No, self-deceiver." In the orchestral accompaniment, moreover, Britten gives sonic flesh to his phantoms: underneath their melodramatic declamation, we hear contrasts of volume and orchestration, which not only differentiate but also seem to physicalize the two ghosts, literalizing their conceptual struggle as a material one. While Miss Jessel reproaches her former lover to the barely audible accompaniment of murmuring strings and timpani rolls, Quint responds with the backing of high, trilling woodwinds (at Figs. 9, 11, and 13). At the same time as choreographing the ghost's movements, however, these striking gestures and timbres go even further to pictorialize their imagery: at Fig. 9, the clarinet's chalumeau trills are hardly subtle in evoking the "terrible sound of the wild swans' wings," while the flute patter after Fig. 11 mimics Miss Jessel's "beating heart."

Elsewhere Britten's melodramatic literalism "stoops" to announcing various characters' entrances and underscoring their movements. The most frivolous instance of such musical "mimomania" - to borrow Nietzsche's term-comes in the second scene, when Miles and Flora practice their bows and curtseys to the synchronized sound of harp glissandi. ${ }^{111}$ A more telling example may be drawn from the final scene with Britten's trademark passacaglia, or "wrong-footed funeral march," as one critic described it. This passage does not merely symbolize the unstoppable march of death, but also seems to choreograph the entrances (first of Miles, then of Quint), before serving as a visceral backdrop to the stagey battle over the boy's soul. ${ }^{12}$ Other intensely rhythmic numbers such as "Tom, Tom, the Piper's Song," from Act I, Scene 5, likewise set the pace for stage movement, choreographing the children's bounding around the stage on their toy hobbyhorse. Indeed, the fact that the opera's most expansive musical forms are all diegetic songs and numbers-from Flora's "Lavender's Blue" to Miles's piano sonata-seems, at first hearing, to assign the music a literalistic or mimetic role. Even the supposedly "pure" interludes and variations, which critics praised enthusiastically with formalist rhetoric, bore pictorial connotations, from the "crunch of the [carriage] wheels on the gravel" in the first interlude, to the bird-like flute arpeggios of the third, to the rippling lake sounds of the sixth.

That such musical mimeticism or sonic literalism fitted oddly with critics' formalistic defenses and psychoanalytic explanations was by no means lost on them. One commentator highlighted the paradox of a score that was "icy, cerebral and artificial" on the one hand, and "directed at the senses" on the other: "It tries to plumb no depths yet the effects are sure, although they hit the solar plexus more than the ear." ${ }^{113}$ In a number of accounts, however, these "ingenuously illustrative" aspects of the score caused considerable concern, one critic denigrating the score for its "skirt[ing] the fringes of the action, ranging from moments of movie-score 
SCENE I. Colloquy and Soliloquy

The lights fade in on Quint and Miss Jessel - nowhere

MISS JESSEL

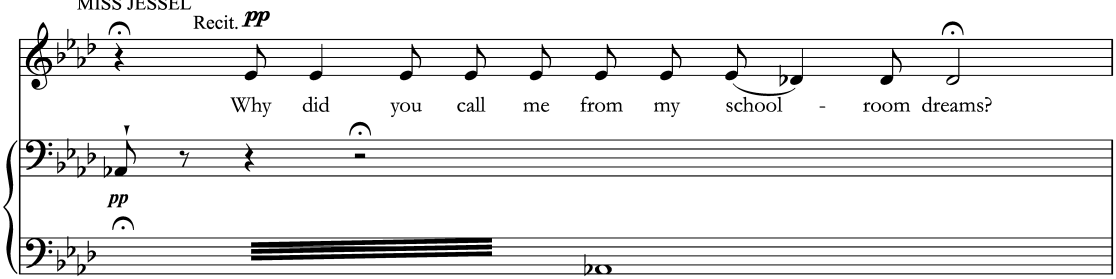

$b \overline{\overline{\mathbf{\boldsymbol { \Theta }}}}$ Db, Timp., Harp

9 QUINT

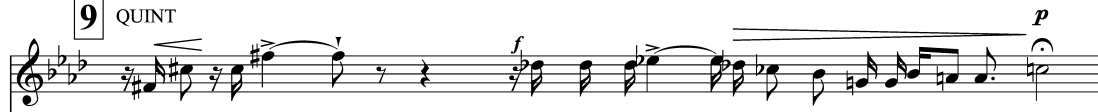

I call? Not I!

You heard the ter

rib-ble sound of thewild swan's wings.

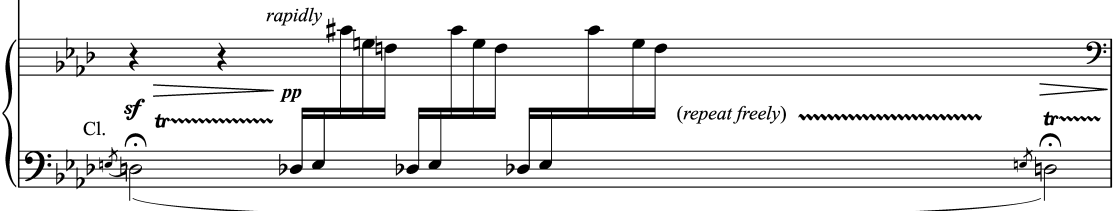

10 MISS JESSEL

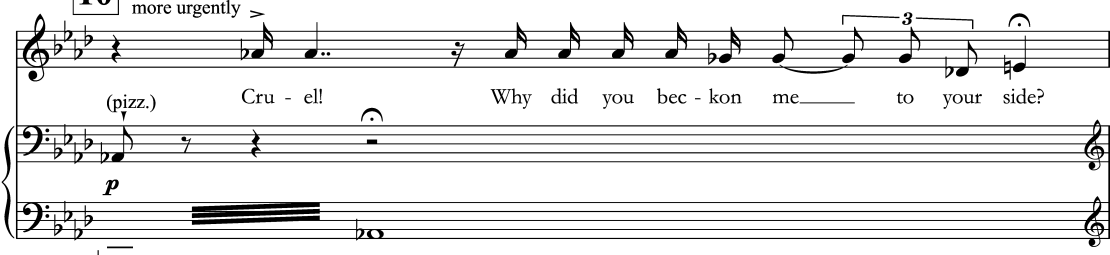

$b \overline{\overline{\mathbf{\Theta}}} \quad$ Db, Timp., Harp

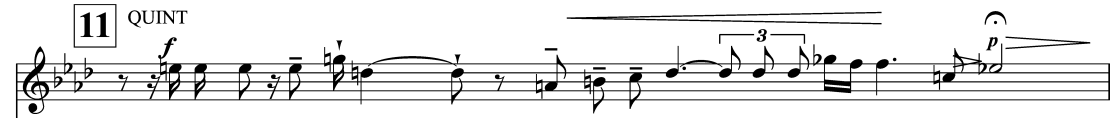

I bec-kon? No, not I!___ Your beat ing heart_ to your own pas - sions lied.

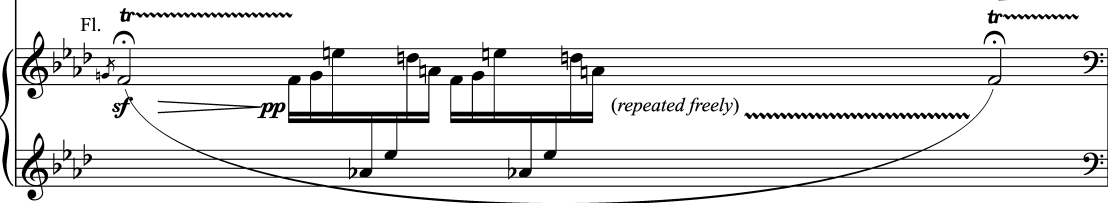

EX. 14. The Turn of the Screw (Act II, Scene 1) - "Colloquy". 

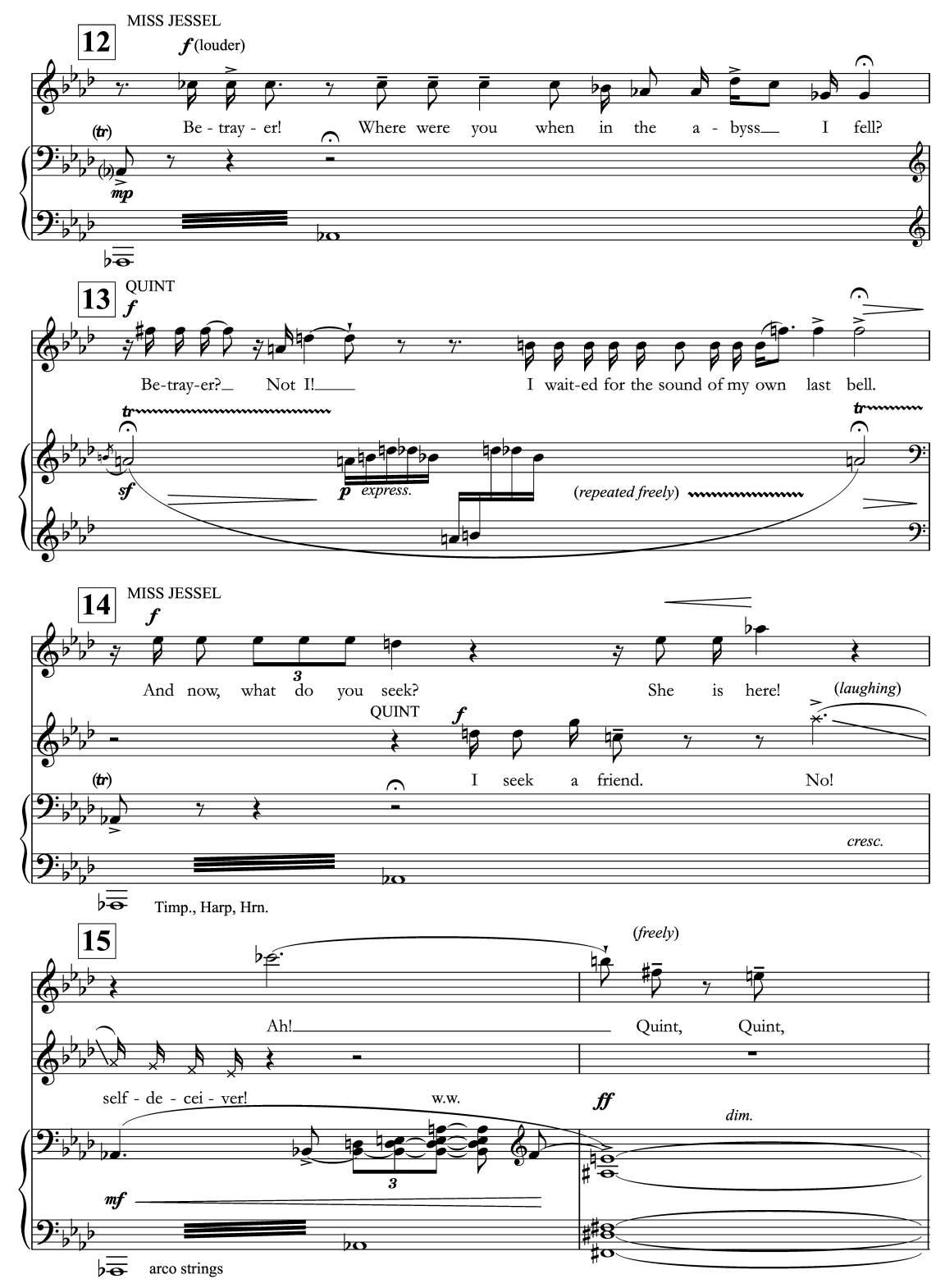

EX. 14 (continued). 
drama to Peter and the Wolf simplicity, including a lilting harp passage to accompany the children and wailing sirens for the ghosts." ${ }^{114}$ Although the film music comparison chimes well with the composer's own remarks that The Turn of the Screw was his "most suitable [opera] for television," it was not intended as a compliment. ${ }^{115}$ In drawing attention to Britten's "wailing sirens," this commentator brought the discussion back to Gothic melodrama. Riccardo Malipiero went further, drawing explicit connections between Britten's illustrative music and a crudely literal reading of James's story: "instead of rising to the peak of the harsh mountain of psychopathic revelation," he explained, "[the expressive crescendo] stops short halfway and remains in the literal, narrative rather than musical and poetic level." ${ }^{116}$

The more sympathetic critics, however, forgave the crude and melodramatic literalism for the sake of Britten's subtle "moods" and "atmospheres." "The fact that all [of the interludes] are variations on one theme ... does not impress one over-much," wrote one "What is delightful is their dramatic effect . . they set the atmosphere for the next scene, and they are never just arbitrary essays in pure music." ${ }^{117}$ Like many others, he praised Britten's subtle attention to sound-color, orchestration, and timbre. "It is evident," another commentator insisted, "that he does not ... first 'compose' a work and then orchestrate it, but that for him the act of creation is a single process." ${ }_{118}$ One Italian commentator dubbed the music "a masterpiece of timbral images," while another enthused: "mature and imaginative command of instrumental timbres seemed entirely successful in creating the various moods." ${ }^{119}$

Despite all the talk of formalism and literalism, then, Britten's music often blurs the boundaries between these extremes. In the markedly "atmospheric" music of the seventh interlude (see Figs. 70-71 in the published score), Britten seems precisely to play with this dividing line. The "screw" theme, singing from deep out of the murky textures, is nothing if not a musical symbol or hermeneutic clue; yet the unusual textures and instrumental effects seem to draw attention to the sonic surface, as if to demand a more immediate response. The celesta arpeggios crystallize this wider ambivalence: they have a partial melodic and motivic identity-as the opera's "second" theme-even as they mimic the lake's rippling waves. Similar in effect are Quint's apparently wordless vocal melismas to Miles at the beginning of the "Night" scene (Ex. 15), an obvious nod to the Gothic "humming and groaning" that Britten and Piper were anxious to avoid. ${ }^{120}$ As the supposedly solid ghost is hidden from view, his voice takes on the air of an acousmêtre, residing-in the words of film theorist Michel Chion- "neither inside nor outside" the narrative. ${ }^{121}$ Like the uncanny sounds of the "Night" interlude from which it springs, the glassy celesta accompaniment, the subtle undulations of the melody, and the soft dynamic swells suggest physical presence and absence by turns.

Even the diegetic songs are repositioned in the space between the literal and the symbolic by a range of musical devices. In “Tom, Tom, the Piper's Son" it is the 

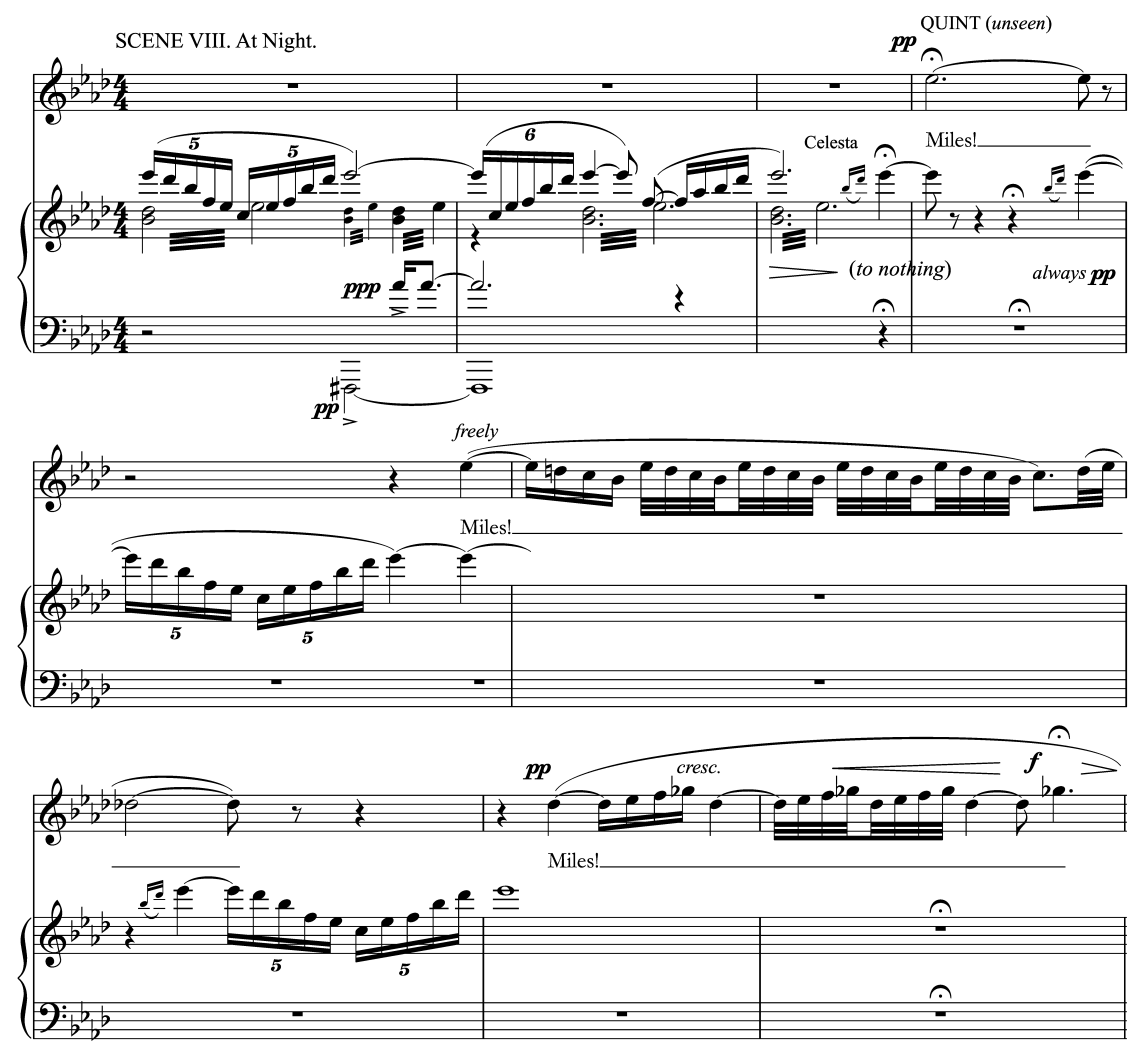

EX. 15. The Turn of the Screw (Act I, Scene 8)- "Miles".

exaggerated physicality and violence of the accompaniment-the harsh timbres and dissonant chord clusters - that simultaneously gesture toward literalism and beyond it, to symbolic excess. In the Act II "Benedicite," the realistic sounds of the church bells and canticle melody are rendered uncanny by chromatic trills, sustained, syncopated chords, harmonic recontextualization, and melodic distortion. Uncanny children's songs, of course, have a considerable history, running from Schubert's death lullabies through Mahler's First Symphony and Berg's Wozzeck to Gothic film scores. More to the point, they played into a broader ambivalence of musical surfaces that both reveal and conceal, whose source and identity raised pressing questions in the listener. Such "atmospheric" music seems to put the audience in the Governess's position, tasked with interpreting a subtle and contradictory sign system that is realistic and obvious on the one hand, and elusive and coded on the other.

Critics who admired the libretto's subtlety found in Britten's "timbral images" comparably redeeming details: "every nuance of action and character finds 
expression in the timbre of the instruments," wrote one. ${ }^{122}$ Another found in these atmospheric timbres the sonic equivalents of the subtle mannerisms with which James had sidestepped Gothic convention: "Mr. Britten . . . elicited from [the ensemble] just such disturbing tones and tonalities, figures and drum-taps, ... as the equivalent of James's mannered periods in the creation of a sinister atmosphere." ${ }^{123}$ Yet these effects stretched back to the literary soundscapes of the earliest Gothic novels: from the wind sighs that double as ghostly whispers in Walpole's Castle of Otranto (1764), to the spectral music and evanescent chanting in Ann Radcliffe's Mysteries of Udolpho (1794), to the oscillation between subtle murmurs and melodramatic laughter at the center of Charlotte Brontës Jane Eyre (1847). ${ }^{124}$ Perhaps even more important for our present purposes, this literary play between exaggerated sound effects and subtle sonic symbolism was actualized in a number of Gothic soundtracks from Britten's own time: from the BBC's Appointment with Fear (1943-1955) to Hitchcock's Rebecca (1940), and the Hammer Horror series that ran in the late 1950 s and 1960 s. ${ }^{125}$

\section{GOTHIC MODERNISM}

In emphasizing these largely overlooked aspects of The Turn of the Screw's miseen-scène, text, and music and tying them to Gothic melodrama, my intention has not been to answer the question that has preoccupied most scholars: whether the work's ghosts are real or imagined, supernatural or psychological. It has been instead to open up a window on the aesthetic stakes, exposing the opera's challenges to the modernist critical tradition. While modernist readings of the opera have generally prevailed in recent scholarship and criticism, reactions to the premiere reveal a more complicated situation, wherein such interpretations were unsettled by associations with Gothic melodrama. The fact that contemporary commentators embraced mutually exclusive interpretations suggests that the problem resided less in the interpretations than in the binary categories to which they appealed.

The wider significance of the opera's fraught reception may be sought here. In their attempts to draw sharp distinctions between a modernist, psychological tale and an old-fashioned, melodramatic ghost story, defenders of Britten in 1954 were participating in a much broader critical trend. By 1921, Birkhead had already predicted that science and psychology would fundamentally remake the Gothic novel for the twentieth century. ${ }^{126}$ By the early 1950s, this transition was supposedly complete:

Ghosts have grown up. Far behind lie their clanking and moaning days; they have laid aside their original bag of tricks-bleeding hands, luminous skulls and so on. Their manifestations are, like their personalities, oblique and subtle, perfectly calculated to get the modern person under the skin. They abjure the over-fantastic and the grotesque, operating, instead, through series of happenings whose horror lies in their being just, just out of the true. Ghosts exploit the horror latent behind reality. ${ }^{127}$ 
Such a distinction between the modern, subtle, psychological ghost story and the Gothic melodrama was almost ubiquitous in early- to mid-twentieth-century criticism. Indeed, for all her attacks on the crudities and excesses of the Gothic novel, even Woolf made room for its supposedly subtle, modern, psychological descendant, inaugurated by the novels of Henry James:

Henry James's ghosts have nothing in common with the violent old ghosts-the blood-stained sea captains, the white horses, the headless ladies of dark lanes and windy commons. They have their origin within us. They are present whenever the significant overflows our powers of expressing it; whenever the ordinary appears ringed by the strange. ${ }^{128}$

This desire to erect overdetermined boundaries was not entirely ingenuous. After all, the modernist canon-from the poetry of Yeats and Eliot, to the novels of Joyce and Forster-hardly lacked ghosts, apparitions, and mysterious voices. Even as Woolf attacked the Gothic supernatural, she penned stories like Mrs. Dalloway (1925) and To the Lighthouse (1927) — not to mention "The Haunted House" and "A Mark on the Wall"-which flirted, sometimes subtly, sometimes not so subtly, with Gothic tropes and conventions. In one of her more candid moments, Woolf admitted that the distinction was less clear-cut than highbrow critics might have imagined. "It would be a fine exercise in discrimination," she remarked, tongue firmly in cheek, "to decide the precise point at which romance becomes Gothic and imagination moonshine ... [A] gift for romance easily escapes control and cruelly plunges its possessor into disrepute." ${ }^{129}$ She then elaborated:

In our days we flatter ourselves that the effect is produced by subtler means. It is at the ghosts within us that we shudder, and not at the decaying bodies of barons or the subterranean activities of ghouls. Yet the desire to widen our boundaries, to feel excitement without danger, and to escape as far as possible from the facts of life drives us perpetually to trifle with the risky ingredients of the mysterious and the unknown. ${ }^{130}$

It would seem, then, that the difference between the two categories she had worked so hard to separate was a matter of degree rather than kind. What is more, Woolf apparently admitted that any lines drawn between them were a matter more of self-flattery than reality. Just as old-fashioned ghost stories were never completely devoid of psychological implication, so it is equally true that modernism's psychological images and projections were never totally free of superstition, excess, and externalized horrors. ${ }^{131}$ Indeed, in its notorious attempts to shock and unsettle audiences, one might even describe modernism as the epitome of Gothic melodrama.

The Turn of the Screw highlights this overlapping of aesthetic oppositions particularly vividly. On the hermeneutic level, it foregrounds both the material reality and psychological invention of James's ghosts, simultaneously invoking and undermining these popular binaries. On an aesthetic level, it navigates between 
suspense-filled subtleties and melodramatic eventfulness. At the same time, Britten's opera also drives home a related musical point: that the archetypes of high modernism and Gothic melodrama could often sound remarkably alike. Many of the score's distinctive features-its atmospheric dissonances, its play with gestural immediacy and formalist abstraction, its loyalties divided between subtle timbral effects, and transgressive rhetorical excess-were as characteristic of musical modernism as of its rejected Gothic other. One recalls that, even as they denounced film composers for reducing musical modernism to the status of a Gothic soundtrack, Adorno and Eisler praised Berg's Lulu for doing something similar: "suspense," they insisted, "is the essence of modern harmony." ${ }^{32}$ Cast as both modernist psychodrama and Gothic melodrama, Britten's Screw arguably did not reconcile aesthetic opposites so much as reveal the unsettling commonalities between two traditions, which commentators fought hard to-but could never quite-separate. 